\title{
Pulmonary function studies in bird breeder's lung
}

\author{
P. D IN DA, S. S. CHAT TER JEE, AND W. D. RIDING \\ From Baguley Hospital, Manchester
}

\begin{abstract}
Pulmonary function studies were performed at the time of diagnosis in 10 patients, aged between 11 and 51 years, with bird breeder's lung due to exposure of between 9 months and 42 years. The studies were repeated after a varying interval in nine of these patients, following removal from exposure. In initial tests, diffusing capacity was impaired in eight patients and the arterial oxygen tension at rest was below $80 \mathrm{~mm}$. $\mathrm{Hg}$ in seven. Five patients had a low vital capacity and three showed evidence of airway obstruction. One patient continued to breed pigeons, against medical advice, and his pulmonary function, repeated after nine months, showed further deterioration. The others with abnormal pulmonary function showed significant improvement on repeat studies. Pulmonary function studies appear to be helpful in the diagnosis, irrespective of radiographic changes, and in the follow-up of patients.
\end{abstract}

Since the description of three patients with acute pneumonitis following exposure to pigeons which they bred as a hobby (Reed, Sosman, and Barbee, 1965), there have been a number of reports of interstitial pulmonary diseases in non-atopic subjects which appear to have been due to hypersensitive reactions to the excreta of both pigeons and budgerigars, similar to those due to other inhaled organic dusts.

The clinical features are characterized by an acute or insidious onset of dyspnoea, tachypnoea, fever, cough, malaise, loss of weight, and crepitations at the lung bases. Radiographs may appear normal or show micronodular shadowing in the early stages, but continued exposure often leads to further mottling, diffuse reticulation, and fibrosis (Leading article, 1967). In the serum of affected patients, specific precipitins have been demonstrated to antigens derived from both pigeon and budgerigar material (Reed et al., 1965 ; Hargreave, Pepys, Longbottom, and Wraith, 1966; Stiehm, Reed, and Tooley, 1967 ; Boyd, Dick, Lorimer, and Moran, 1967), though the presence of serum precipitins in bird breeders without any pulmonary symptom is not uncommon (Hargreave et al., 1966 ; Maloney, 1967). In most patients, intracutaneous tests with extracts of serum or droppings give a late Arthus-type response with an occasional immediate reaction. Aerosol challenge with appropriate antigen has been used as a diagnostic aid in adults, but such provocative tests do not seem to be an essential procedure (Stiehm et al., 1967).

The purpose of the present study is to present data of some of the main lung function changes in bird breeder's lung and to demonstrate the effect of removal from the source of exposure on these changes.

\section{MATERIALS AND METHODS}

Ten patients with bird breeder's lung were studied. Dstails of their age, sex, exposure to birds, radiological features, serum precipitin, and skin tests are shown in Table I. All had typical clinical features and positive precipitin tests against avian antigens, and five out of nine patients had a positive delayed reaction to intracutaneous skin tests with extracts from feathers.

Pulmonary function studies were performed at the time of diagnosis in all patients and were repeated several times in all except one (whom we were not able to trace) following removal from exposure. Only the results of the first and the last tests are discussed here.

The vital capacity (V.C.), forced expiratory volume

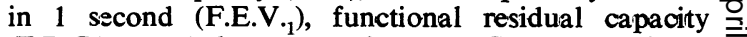
(F.R.C.), total lung capacity (T.L.C.) and residual $\vec{N}$ volume (R.V.) were determined, using the closed- of circuit helium dilution method (Gilson and Hugh- N Jones, 1949) in a twin spirometer with helium analyser N (Godard Pulmotest). Predicted values were obtained $\omega$ from the standard nomograms (Miller, Johnson, and Wu, 1959 ; Goldman and Becklake, 1959). The ratio F.E.V.1/V.C. was calculated and values below $70 \%$ were regarded as abnormal. The nitrogen washout $\stackrel{\infty}{\rightarrow}$ time was measured by breath to breath analysis with 0 $100 \%$ oxygen breathing, recorded in a single channel $\bar{O}$ recorder; expired nitrogen was analysed by the $\mathbb{\Phi}$ Nitromed Analyser (Lundin, 1953).

The steady-state carbon monoxide diffusing capacity $\stackrel{\square}{\square}$ (Dico) was estimated at rest and on exercise. The apparatus and method used were as described by 8 
T A B L E I

CHARACTERISTICS AT TIME OF DIAGNOSIS

\begin{tabular}{|c|c|c|c|c|c|c|c|c|c|c|c|}
\hline \multirow{3}{*}{ No. } & \multirow{3}{*}{$\begin{array}{l}\text { Age/ } \\
\text { Sex }\end{array}$} & \multirow{3}{*}{ Bird } & \multirow{3}{*}{$\begin{array}{l}\text { Duration } \\
\text { of } \\
\text { Contact }\end{array}$} & \multirow{3}{*}{$\begin{array}{c}\text { Duration } \\
\text { of } \\
\text { Symp- } \\
\text { toms }\end{array}$} & \multirow{3}{*}{ Chest Radiograph } & \multicolumn{4}{|c|}{ Precipitin Test } & \multirow{2}{*}{\multicolumn{2}{|c|}{$\begin{array}{c}\text { Skin Test } \\
\text { (delayed reaction) }\end{array}$}} \\
\hline & & & & & & \multicolumn{2}{|c|}{ Pigeon } & \multicolumn{2}{|c|}{ Budgerigar } & & \\
\hline & & & & & & Serum & $\underset{\text { Extract }}{\text { Dropping }}$ & Serum & $\begin{array}{c}\text { Dropping } \\
\text { Extract }\end{array}$ & Pigeon & $\begin{array}{l}\text { Budgeri- } \\
\text { gar }\end{array}$ \\
\hline 1 & $11 \mathrm{M}$ & Budgerigar & $18 \mathrm{mths}$ & $1 \mathrm{yr}$ & Heavy vascular markings & Negative & Negative & Positive & Negative & Positive & Positive \\
\hline $\begin{array}{l}2 \\
3\end{array}$ & $\begin{array}{l}30 \mathrm{M} \\
42 \mathrm{M}\end{array}$ & $\begin{array}{l}\text { Pigeon } \\
\text { Pigeon } \\
\text { Budgerigar }\end{array}$ & $\begin{array}{l}5 \text { yrs } \\
35 \text { yrs } \\
30 \text { yrs }\end{array}$ & $\begin{array}{l}18 \text { mths } \\
2 \text { yrs }\end{array}$ & $\begin{array}{l}\text { Miliary mottling all over } \\
\text { Normal }\end{array}$ & $\begin{array}{l}\text { Positive } \\
\text { Positive }\end{array}$ & $\begin{array}{l}\text { Positive } \\
\text { Positive }\end{array}$ & 二 & $\begin{array}{l}\text { Positive } \\
\text { Negative }\end{array}$ & $\begin{array}{l}\text { Negative } \\
\text { Negative }\end{array}$ & $\begin{array}{l}\text { Negative } \\
\text { Negative }\end{array}$ \\
\hline $\begin{array}{l}4 \\
5\end{array}$ & $\begin{array}{l}43 \mathrm{M} \\
44 \mathrm{M}\end{array}$ & $\begin{array}{l}\text { Budgerigar } \\
\text { Pigeon } \\
\text { Budgerigar }\end{array}$ & $\begin{array}{r}5 \text { yrs } \\
20 \text { yrs } \\
2 \text { yrs }\end{array}$ & $\begin{array}{l}1 \mathrm{yr} \\
6 \mathrm{mths}\end{array}$ & $\begin{array}{l}\text { Normal } \\
\text { Bilateral diffuse reticulo- } \\
\text { nodular shadowing in }\end{array}$ & $\begin{array}{l}\text { Negative } \\
\text { Positive }\end{array}$ & $\begin{array}{l}\text { Negative } \\
\text { Positive }\end{array}$ & - & $\begin{array}{l}\text { Positive } \\
\text { Positive }\end{array}$ & $\begin{array}{l}\text { Negative } \\
\text { Not per }\end{array}$ & $\begin{array}{l}\text { Negative } \\
\text { formed }\end{array}$ \\
\hline $\begin{array}{l}6 \\
7\end{array}$ & $\begin{array}{l}46 M \\
47 M\end{array}$ & $\begin{array}{l}\text { Budgerigar } \\
\text { Budgerigar }\end{array}$ & $\begin{array}{l}2 \text { yrs } \\
15 \text { yrs }\end{array}$ & $\begin{array}{r}18 \text { mths } \\
6 \text { mths }\end{array}$ & $\begin{array}{l}\text { lower zones } \\
\text { Normal } \\
\text { Bilateral diffuse reticulo- } \\
\text { nodular shadowing in }\end{array}$ & $\begin{array}{l}\text { Negative } \\
\text { Negative }\end{array}$ & $\begin{array}{l}\text { Positive } \\
\text { Negative }\end{array}$ & - & $\begin{array}{l}\text { Positive } \\
\text { Positive }\end{array}$ & $\begin{array}{l}\text { Negative } \\
\text { Negative }\end{array}$ & $\begin{array}{l}\text { Positive } \\
\text { Positive }\end{array}$ \\
\hline 8 & $51 \mathrm{M}$ & Pigeon & 42 yrs & 5 yrs & $\begin{array}{l}\text { lower zones } \\
\text { Bilateral diffuse reticulo- } \\
\text { nodular shadowing in }\end{array}$ & Positive & Positive & - & Negative & Positive & Negative \\
\hline 9 & $13 \mathrm{~F}$ & Budgerigar & 13 yrs & 3 yrs & $\begin{array}{l}\text { lower and mid zones } \\
\text { Minimal miliary mottling } \\
\text { in mid and lower zones }\end{array}$ & Positive & Positive & - & Positive & Negative & Negative \\
\hline 10 & $37 \mathbf{F}$ & Budgerigar & $9 \mathrm{mths}$ & $6 \mathrm{mths}$ & $\begin{array}{l}\text { on both sides } \\
\text { Normal }\end{array}$ & Negative & Negative & Negative & Positive & Negative & Positive \\
\hline
\end{tabular}

MacNamara, Prime, and Sinclair (1959) and the normal values they obtained were used for comparison. Transfer factor (TL) was measured in some patients in the later part of the study, using an automatic spirometer (Resparameter Mk. 4, P. K. Morgan Ltd.) as described by Meade, Saunders, Hyett, Reynolds, Pearl, and Cotes (1965).

Blood gas studies were obtained from the arterialized capillary blood (Paine, Boutwell, and Soloff, 1961), analysed by the Radiometer capillary electrode system using the Astrup technique. The $p \mathrm{H}$ and partial pressures of $\mathrm{O}_{2}$ were measured directly, (and the partial pressure of carbon dioxide $\left(\mathrm{PCO}_{2}\right)$ and plasma bicarbonate were calculated from nomograms (Siggaard Andersen and Engel, 1960). Normal values for arterial blood gases were obtained from the
National Academy of Sciences Handbook of Respiration (1958).

\section{RESULTS}

Details of the pulmonary function tests are shown, with dates, in Table II and in the Figure. We found a higher degree of repeatability in the parameters measured.

VENTILATORY FUNCTION AND STATIC LUNG VOLUME In initial tests the vital capacity was less than $80 \%$ of the predicted value in five patients. The F.E.V. $._{1} /$ V.C. ratio was below $70 \%$ in only three patients and the response to isoprenaline inhala-

T A B L E I I

MAIN PULMONARY FUNCTION CHANGES IN BIRD BREEDER'S LUNG

\begin{tabular}{|c|c|c|c|c|c|c|c|c|c|c|c|c|}
\hline \multirow[t]{2}{*}{ No. } & \multirow[t]{2}{*}{ Date } & \multirow[t]{2}{*}{$\begin{array}{l}\text { V.C. } \\
\text { (1.) }\end{array}$} & \multirow{2}{*}{ 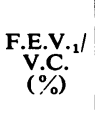 } & \multirow[t]{2}{*}{$\underset{\text { (I.) }}{\text { F.R.C. }}$} & \multirow[t]{2}{*}{$\underset{\text { (1.) }}{\text { T.L.C. }}$} & \multirow{2}{*}{$\underset{(\%)}{\text { R. }}$} & \multirow{2}{*}{$\begin{array}{c}\mathbf{N}_{2} \\
\text { Wash-out } \\
\text { (min.) }\end{array}$} & \multicolumn{2}{|c|}{$\begin{array}{c}\text { DLco } \\
\text { (ml./min./ } \\
\mathrm{mm} . \mathrm{Hg})\end{array}$} & \multirow{2}{*}{$\begin{array}{c}\text { TL } \\
(\mathrm{ml} . / \mathrm{min} . / \\
\mathrm{mm} . \mathrm{Hg})\end{array}$} & \multirow{2}{*}{$\begin{array}{c}\mathrm{Po}_{2} \\
\text { Rest } \\
\text { (mm. Hg) }\end{array}$} & \multirow[t]{2}{*}{$\underset{(\mathrm{mm} . \mathrm{Hg})}{\mathrm{PCO}_{2}}$} \\
\hline & & & & & & & & Rest & Exercise & & & \\
\hline $\begin{array}{r}1 \\
2 \\
3 \\
4 \\
5 \\
6 \\
7 \\
8 \\
9 \\
10\end{array}$ & $\begin{array}{r}\text { 17. } 8.67 \\
24.5 .68 \\
21.7 .67 \\
28.5 .68 \\
22.12 .67 \\
4.6 .68 \\
28.11 .67 \\
15.3 .66 \\
19.7 .68 \\
13.10 .67 \\
\text { 31. } 5.68 \\
5.3 .68 \\
18.6 .68 \\
22.8 .67 \\
11.6 .68 \\
18.8 .67 \\
24.5 .68 \\
11.4 .68 \\
\text { 7. } 6.68\end{array}$ & $\begin{array}{l}1 \cdot 5 \\
2 \cdot 3 \\
3 \cdot 1 \\
5 \cdot 8 \\
5 \cdot 4 \\
4 \cdot 6 \\
3 \cdot 5 \\
2 \cdot 1 \\
4 \cdot 2 \\
4 \cdot 1 \\
4 \cdot 2 \\
3 \cdot 4 \\
2 \cdot 9 \\
3 \cdot 6 \\
3 \cdot 3 \\
2 \cdot 4 \\
3 \cdot 3 \\
3 \cdot 0 \\
2 \cdot 9\end{array}$ & $\begin{array}{l}53 \\
70 \\
93 \\
72 \\
70 \\
70 \\
73 \\
62 \\
74 \\
73 \\
71 \\
85 \\
93 \\
64 \\
70 \\
79 \\
91 \\
73 \\
69\end{array}$ & $\begin{array}{l}1 \cdot 4 \\
2 \cdot 2 \\
3 \cdot 5 \\
3 \cdot 0 \\
3 \cdot 3 \\
3 \cdot 2 \\
4 \cdot 8 \\
2 \cdot 3 \\
2 \cdot 4 \\
4 \cdot 1 \\
4 \cdot 7 \\
2 \cdot 1 \\
2 \cdot 9 \\
3 \cdot 5 \\
4 \cdot 6 \\
1 \cdot 2 \\
2 \cdot 0 \\
2 \cdot 6 \\
2 \cdot 0\end{array}$ & $\begin{array}{l}2 \cdot 6 \\
3 \cdot 8 \\
5 \cdot 7 \\
7 \cdot 2 \\
6 \cdot 8 \\
7 \cdot 0 \\
6 \cdot 7 \\
4 \cdot 2 \\
5 \cdot 1 \\
6 \cdot 7 \\
7 \cdot 1 \\
4 \cdot 4 \\
5 \cdot 0 \\
5 \cdot 7 \\
6 \cdot 9 \\
2 \cdot 7 \\
4 \cdot 3 \\
4 \cdot 4 \\
3 \cdot 9\end{array}$ & $\begin{array}{l}42 \\
39 \\
46 \\
19 \\
20 \\
34 \\
44 \\
48 \\
18 \\
58 \\
41 \\
23 \\
42 \\
37 \\
52 \\
11 \\
23 \\
32 \\
26\end{array}$ & $\begin{array}{l}3-5 \\
1-55 \\
2-20 \\
1-5 \\
1-20 \\
0-45 \\
5-0 \\
2-0 \\
0-14 \\
2-30 \\
1-50 \\
0-50 \\
0-45 \\
5-0 \\
3-5 \\
1-15 \\
0-35 \\
1-0 \\
1-20\end{array}$ & $\begin{array}{r}5 \cdot 4 \\
13 \cdot 1 \\
6 \cdot 2 \\
13.9 \\
23 \cdot 7 \\
28.9 \\
10 \cdot 9 \\
4 \cdot 6 \\
8 \cdot 1 \\
14 \cdot 3 \\
13 \cdot 3 \\
12 \cdot 6 \\
14 \cdot 4 \\
10 \cdot 9 \\
8 \cdot 8 \\
6 \cdot 3 \\
10 \cdot 8 \\
6.5 \\
10 \cdot 8\end{array}$ & $\begin{array}{r}11 \cdot 0 \\
23.8 \\
14.8 \\
22.8 \\
48 \cdot 5 \\
42.3 \\
20.5 \\
3.4 \\
15 \cdot 3 \\
23.9 \\
24 \cdot 1 \\
12.6 \\
22.2 \\
18.6 \\
12.2 \\
11.7 \\
16.8 \\
10.4 \\
19.6\end{array}$ & $\begin{array}{l}\overline{19 \cdot 4} \\
\overline{23 \cdot 6} \\
\overline{31 \cdot 8} \\
\overline{-} \\
\overline{13 \cdot 2} \\
\overline{25 \cdot 5} \\
16 \cdot 0 \\
16 \cdot 2 \\
\overline{21 \cdot 8} \\
\overline{18 \cdot 3} \\
\overline{18 \cdot 1}\end{array}$ & $\begin{array}{l}60 \\
73 \\
68 \\
71 \\
- \\
75 \\
64 \\
76 \\
80 \\
85 \\
61 \\
76 \\
75 \\
80 \\
70 \\
86 \\
90 \\
\end{array}$ & $\begin{array}{l}32 \\
36 \\
30 \\
33 \\
\overline{42} \\
37 \\
38 \\
30 \\
35 \\
34 \\
34 \\
35 \\
40 \\
32 \\
42 \\
34 \\
\end{array}$ \\
\hline
\end{tabular}



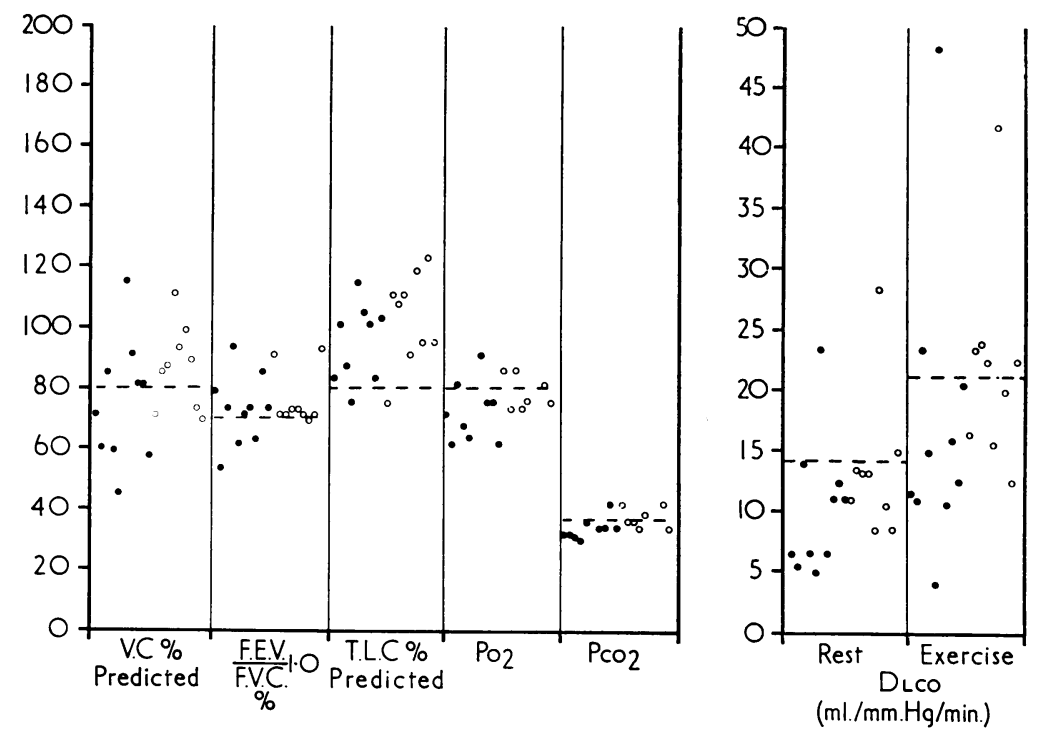

FIGURE. Main changes in pulmonary function in patients with bird breeder's lung: -, results of initial study; $\bigcirc$, results of repeat study; - - , indicate the lower limit of normal range.

tion was slight. Five patients had a minute ventilation of more than 9 litres per minute.

Low values were found for the total lung capacity in two patients, for the residual volume in two patients, and for the functional residual capacity in four patients. In patient 6 , the residual volume was raised. The R.V./T.L.C. ratio corresponded closely to the figures obtained for R.V. The nitrogen washout time, to detect any impairment of pulmonary gas mixing, was within normal range in all.

CARBON MONOXIDE DIFFUSING CAPACITY Eight of the 10 patients showed impairment of diffusing capacity at rest and on exercise. The results were normal in patient 3 and border-line in patient 6 .

BLOOD GAS ESTIMATIONS These were performed in nine patients with arterialized capillary blood. In seven, $\mathrm{Po}_{2}$ was below $80 \mathrm{~mm}$. $\mathrm{Hg}$ at rest. The $\mathrm{PCO}_{2}$ level was below normal in seven, and in none was it elevated. The blood $p \mathrm{H}$ was normal and the plasma bicarbonate slightly low in all patients.

REPEAT PULMONARY FUNCTION STUDIES (Table II) Nine patients were available for repeat pulmonary function studies following cessation of exposure to avian antigens. All had subjective improvement, except patient 8 , whose symptoms were originally not severe and who continued to breed pigeons. This patient's pulmonary function, repeated after nine months, showed further deterioration. The others showed improvement in almost all of the previously abnormal parameters of pulmonary function, except patients 3 and 6 whose pulmonary functions were normal at the time of diagnosis. The transfer factor showed good correlation with the Dico.

\section{DISCUSSION}

Bird breeder's lung exemplifies a large group of interstitial pulmonary diseases, occurring as a result of inhaled antigens. This develops after a period of exposure to pigeon or budgerigar, the interval varying from a few months to over 30 years (Hargreave et al., 1966), and has also been observed in the present series. Chest radiographs may be normal, as they were in four of our patients, whereas abnormalities in pulmonary function are more frequent in this condition. In our series, five patients showed demonstrable radiographic changes and eight patients had impairment of pulmonary function. Two patients with a typical history of symptoms developing repeatedly after exposure to birds had norma radiographs and pulmonary function. On remova 
from exposure there was no recurrence. Had they been examined at the height of their symptoms, it is likely that the pulmonary function tests would have been abnormal at that time.

Reported pulmonary function studies in bird breeder's lung have shown moderate to severe reduction in vital capacity, little or no airway obstruction, moderate reduction in diffusing capacity, arterial hypoxia, and small alterations in the lung volumes (Reed et al., 1965 ; Hargreave et al., 1966; Stiehm et al., 1967). These abnormalities are compatible with the pathological changes in the peripheral gas-exchanging tissue of the lungs where the main changes are interstitial inflammation and alveolar exudation, without significant involvement of the bronchial tree or blood vessels.

Our findings are similar to those previously reported. Half of the patients had a reduction of vital capacity while the total lung capacity was below the predicted value in only two patients. One, patient 6 , had an abnormally high residual volume, though his total lung capacity, pulmonary gas mixing efficiency, and diffusion studies were within normal limits. On subsequent examination of the same patient, however, the residual volume was found to be near normal. The diffusing capacity was impaired in the majority of patients and was the most common abnormality found in our group.

Seven patients had low arterial oxygen tension at rest. This, we believe, is due to increased venous admixture, possibly caused by a reduction in the rate of gas transfer. As pulmonary capillary volume was not measured, alterations of the pulmonary vascular bed cannot be excluded.

Hyperventilation is a common feature of 'stiff lung' where this is due to alteration at the alveolar region. This has been reported in patients with diffuse fibrosing alveolitis and other interstitial pulmonary disorders. In our series, this pattern has been observed, and in the majority of the patients the $\mathrm{PCO}_{2}$ remained low; the highest reading obtained was $42 \mathrm{~mm}$. $\mathrm{Hg}$.

Except for one patient of Stiehm et al. (1967), all cases reported previously by different authors had no evidence of airway obstruction, though wheezing was a feature in two patients in one series (Hargreave et al., 1966). In the same series, however, few of the patients showed a significant reduction of F.E.V.$_{1}$ after inhalation tests. In our group, two patients had mild and one (patient 1) moderate airway obstruction. There was no evidence of airway obstruction on repeat pul- monary function testing in these patients. The airway obstruction was not reversed completely by isoprenaline inhalation. This finding, along with impaired diffusing capacity, contrasts with bronchial asthma, where usually airways obstruction is reversible and diffusing capacity is normal. Mild airway obstruction in some of our cases may be due to bronchiolar obstruction. Similar findings have been reported in some cases of farmer's lung (Williams, 1963).

All our patients were advised to dispose of their pigeons or budgerigars. One, patient 8 , failed to do this and showed further deterioration of his pulmonary function during the continued exposure. All the other patients, in whom pulmonary function was abnormal during the initial testing, showed improvement on repeat testing following a lapse of varying periods. In those patients who showed initial impairment of diffusing capacity, the Dico, although improved, remains low. This requires further study. Two patients, 5 and 10, were treated with corticosteroids for a period of 3-12 months and, although they did not show a greater improvement in lung function than other patients, subjective improvement was more rapid.

The changes in pulmonary function in bird breeder's lung are not specific, as similar changes are found in other diseases which involve the pulmonary alveolar tissue, such as farmer's lung, sarcoidosis, scleroderma, diffuse fibrosing alveolitis, and other interstitial pulmonary diseases. However, with pulmonary symptoms and a history of exposure to pigeon or budgerigar, pulmonary function studies appear to be helpful in the diagnosis and assessment of progress.

We wish to thank Dr. J. Miles Walker for patients 3 and 5, and Dr. J. D. Allan for patients 1 and 9 ; all the technicians of our respiratory laboratory for additional work and inconvenience; Mrs. L. Denison for secretarial help; and Professor J. Pepys, of the Brompton Hospital, for carrying out the precipitin tests.

We are most grateful to Dr. T. M. Wilson for his helpful criticism of the manuscript.

\section{REFERENCES}

Boyd, G., Dick, H. W., Lorimer, A. R., and Moran, F. (1967). Bird breeder's lung. Scot. med. J., 12, 69 .

Gilson, J. C., and Hugh-Jones, P. (1949). The measurement of the total lung volume and breathing capacity. Clin. Sci., 7, 185.

Goldman, H. I., and Becklake, M. R. (1959). Respiratory function tests: Normal values at median altitudes and the prediction of normal results. Amer. Rev. Tuberc., 79, 457.

Hargreave, F. E., Pepys, J., Longbottom, J. L., and Wraith, D. G. (1966). Bird breeder's (fancier's) lung. Lancet, 1, 445.

Leading article (1967). Bird fancier's lung. Brit. med. J., 2, 713.

Lundin G. (1953). Nitrogen elimination dur!ng oxygen breathing. Acta physiol. scand., 30, Suppl. 111, p. 130. 
MacNamara, J., Prime, F. J., and Sinclair, J. D. (1959). An assessment of the steady-state carbon monoxide method of estimating pulmonary diffusing capacity. Thorax, 14, 166.

Maloney, P. (1967). Pigeon breeder's lung. Med. J. Aust., 1, 969.

Meade, F., Saunders, M. J., Hyett, F., Reynolds, J. A., Pearl, N., and Cotes, J. E. (1965). Automatic measurement of lung function. Lancet, 2, 573.

Miller, W. F., Johnson, Jr., R. L., and Wu, N. (1959). Relationships between fast vital capacity and various timed expiratory capacities. J. appl. Physiol., 14, 157.

National Academy of Sciences-National Research Council (1958). Handbook of Respiration. 1st ed., p. 57. Ed. Dittmer, D. S., and Grebe, R. M. Saunders, Philadelphia.
Paine, E. G., Boutwell, J. H., and Soloff, L. A. (1961). The reliability of "arterialized" venous blood for measuring arterial $\mathrm{pH}$ and $\mathrm{FCO}_{2}$. Amer. J. med. Sci., 242, 431.

Reed, C. E., Sosman, A., and Barbee, R. A. (1965). Pigeon-breeders' lung. J. Amer. med. Ass., 193, 261.

Siggaard Andersen, O., and Engel, K. (1960). A new acid-base nomogram. An improved method for the calculation of the relevant blood acid-base data. Scand. J. clin. Lab. Invest., $12,177$.

Stiehm, E. R., Reed, C. E., and Tooley, W. H. (1967). Pigeon breeder's lung in children. Pediatrics, 39, 904.

Williams, J. V. (1963). Pulmonary function studies in patients with farmer's lung. Thorax, 18, 255 